\title{
Optimization of Some Parameters for Polymerase Chain Reaction (PCR) Amplification of CTLA-4 Gene from Blood Samples of Rheumatoid Arthritis Patients
}

Meenakshi Lal, Sanjeev Ranjan*

Orange Life Sciences, Visakhapatnam, 530027, India

DOI: $10.36347 / \mathrm{sajb} .2020 . v 08 i 08.004$

| Received: 13.08.2020 | Accepted: 21.08.2020 | Published: 28.08.2020

*Corresponding author: Sanjeev Ranjan

Abstract

Original Research Article

Optimization of PCR is very important as it is a time taking hectic procedure which once done can save a lot of important time and confusion in genetic studies involving gene amplification using PCR. The CTLA-4 gene has been found to be associated with many autoimmune diseases including rheumatoid arthritis [1]. The present study was performed to optimize the Polymerase chain reaction (PCR) amplification of CTLA-4 gene from genomic DNA isolated from rheumatoid arthritis patients. The conditions were optimized for different parameters such as Taq DNA polymerase concentration, dNTPs concentrations, Primer concentrations, $\mathrm{MgCl}_{2}$ concentration and different enhancing agents. The results obtained were used to develop the protocol for amplification reaction. The study can be useful for researchers looking for quick amplification of the gene under study using the optimized conditions without going through the complex procedures.

Keywords: PCR Optimization, CTLA-4, Rheumatoid Arthritis, DNA amplification.

Copyright @ 2020: This is an open-access article distributed under the terms of the Creative Commons Attribution license which permits unrestricted use, distribution, and reproduction in any medium for non-commercial use (NonCommercial, or CC-BY-NC) provided the original author and source are credited

\section{INTRODUCTION}

The polymerase chain reaction (PCR) is one of the most powerful and essential techniques in molecular biology research where amplification of DNA is done by using a DNA template, Nucleotide triphosphates (dNTPs), DNA Polymerase enzyme and some chemical reagents [2]. The use of PCR technique has massively expanded among molecular scientists because of its ability to amplify target regions of template DNA in a much shorter time which can be of great help in detecting the presence of a particular gene for molecular diagnostic purpose or identifying multiple regions on genome for forensic use or isolating and preparing a gene insert for cloning experiments by the repetition of typically 30-50 replication cycles that double the target DNA molecules at each cycle [3]. A typical PCR consists of three stages: 1) a denaturation stage (1-2 min); 2) a primer annealing (hybridization) stage (1-2 $\mathrm{min})$, and 3 ) an extension stage (1-2 $\mathrm{min}$ ) for several cycles [4].

Because a PCR involves multiple components like PCR buffer, Taq polymerase, dNTP mix, $\mathrm{MgCl}_{2}$, Primers and enhancing agents; which cause complex interactions among the components of PCR and due to wide variety of its application, it is very unlikely that one set of amplification conditions would be optimal for all situations [5]. Several changes can be made to the PCR composition in order to optimize the reaction [6]. Some parameters that should be of concern in order to facilitate the optimization process are chemical concentrations ( $\mathrm{MgCl} 2$, dNTP mix, PCR buffer, and Taq polymerase), primers used and PCR conditions that include the highest annealing temperature, optimal cycle number and amplification duration $[7,8]$.

Rheumatoid arthritis (RA) is a complex autoimmune disorder, characterized by a chronic T-cell response that has evaded normal control mechanisms [9]. Therefore, the genes involved in the regulation of T-cell responses may be primary determinants of susceptibility to RA. CTLA-4 is a key negative regulator of T-cell activation [10] and is considered a candidate gene for autoimmune diseases including RA [1]. Type 1 diabetes, as well as autoimmune thyroid diseases (AITDs) such as Graves' and Hashimoto disease, is said to be a T-cell-mediated autoimmune disease [11-15]. Because CTLA-4 is an important gene having its role in RA as well as many other autoimmune diseases Therefore, the main aim of the present study was to optimise the concentrations of Taq polymerase, dNTPs, $\mathrm{MgCl}_{2}$, Primers and enhancing agents for the PCR amplification of CTLA-4 gene. 


\section{MATERIALS AND METHODS}

\section{Sample collection}

The blood samples were collected by Dr. Lakshmi Kanth of Steel Plant Hospital in sterile collection tubes. A total of 18 diseased samples were collected from persons suffering from rheumatoid arthritis. The samples were transferred to the lab immediately after collection.

\section{Sample storage}

The blood samples were stored at $-20^{\circ} \mathrm{C}$ until further process. For DNA isolation, the samples were thawed at room temperature and used. The samples were further stored at $4^{0} \mathrm{C}$.

\section{DNA isolation}

Genomic DNA from whole blood was extracted using RBC lysis buffer with proteinase $\mathrm{K}$ followed by purification using Phenol Chloroform Isoamyl alcohol.
Finally DNA was precipitated using ice cold 95\% ethanol, centrifuged and then resuspended in Tris EDTA Buffer. The genomic DNA was confirmed by $1 \%$ agarose gel electrophoresis (Process explained under analysis of PCR products).

\section{Primer designing for Polymerase Chain Reaction}

The sequence of human CTLA-4 gene was retrieved from the website of National Center for Biotechnology Information (http://www.ncbi.nlm.nih.gov/). The primers for polymerase chain reaction were designed by using WEBPRIMER 3.0 software. The software requires the gene sequence in FASTA format and other parameters details like $\mathrm{T}_{\mathrm{m}}$ value, $\mathrm{GC}$ content, self-annealing temperature, etc.

Following was the primer sequence hence obtained which would give a PCR product of 6199 base pairs length:

\section{\begin{tabular}{|l|l|l|l|}
\hline Forward-Primer & CACGCAAGCTTTCTATTCAAG & Reverse-Primer & GGAAAACGACCACCACAGATT \\
\hline
\end{tabular}}

Reaction conditions for PCR

\begin{tabular}{|l|l|l|l|l|l|}
\hline Initial denaturation & Denaturation & Annealing & Extension & Final extension & Hold \\
\hline $95^{\circ} \mathrm{C}$ & $94^{\circ} \mathrm{C}$ & $56^{\circ} \mathrm{C}$ & $72^{\circ} \mathrm{C}$ & $72^{\circ} \mathrm{C}$ & $4{ }^{\circ} \mathrm{C}$ \\
\hline $2 \mathrm{~min}$ & $30 \mathrm{sec}$ & $30 \mathrm{sec}$ & $30 \mathrm{sec}$ & $2 \mathrm{~min}$ & $\infty$ \\
\hline & \multicolumn{4}{|r}{$-35 \mathrm{cycles}$} & \\
\hline
\end{tabular}

\section{Analysis of PCR products}

The PCR products were confirmed and analysed using $2 \%$ agarose gel electrophoresis. Before loading of the samples gel loading buffer containing bromophenol blue as tracking dye was added. DNA fragments were labelled by adding ethidium bromide in the gel which allows visualization of the DNA bands under UV light.

\section{Effect of Taq DNA polymerase concentration}

The effect of different concentrations of Taq DNA polymerase on the amplification of CTLA4 gene was evaluated using PCR. The amount of Taq DNA

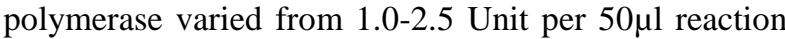
mixture.

Table-1: Reaction mixture for optimising Taq Polymerase concentration for PCR amplification of CTLA-4 gene.

\begin{tabular}{|l|l|}
\hline Template DNA & $2 \mu l$ \\
\hline Forward primer & $2 \mu l$ \\
\hline Reverse primer & $2 \mu l$ \\
\hline dNTPs & $2 \mu l$ \\
\hline Taq DNA polymerase assay buffer $(10 \mathrm{X})$ & $5 \mu \mathrm{l}$ \\
\hline Taq DNA polymerase & $\begin{array}{l}\text { Diluted accordingly to make concentrations } 1.0,1.25,1.5,1.75,2.0 \\
\& 2.5 \mathrm{U} \text { in } 6 \text { different tubes }\end{array}$ \\
\hline PCR grade water & To make up total volume up to $50 \mu 1$ \\
\hline
\end{tabular}

Effect of Deoxynucleotide Tri- Phosphates (dNTPs)

The concentrations of dNTPs used in a reaction mixture were determined by the affinity of Taq DNA polymerase for dNTP as substrate. Thus only dNTPs at a minimum required concentration would be able to amplify the gene under study to an amount sufficient to give rise to a visible band. 
Meenakshi Lal \& Sanjeev Ranjan., Sch Acad J Biosci, August, 2020; 8(8): 249-254

Table-2: Reaction mixture for optimising dNTP concentration for PCR amplification of CTLA-4 gene

\begin{tabular}{|l|l|}
\hline Template DNA & $2 \mu 1$ \\
\hline Forward primer & $2 \mu \mathrm{l}$ \\
\hline Reverse primer & $2 \mu \mathrm{l}$ \\
\hline dNTPs & Sufficiently diluted to make final concentration up to 200-1000 $\mu \mathrm{M}$ \\
\hline Taq DNA polymerase assay buffer (10X) & $5 \mu \mathrm{l}$ \\
\hline Taq DNA polymerase & $1 \mu \mathrm{l}$ \\
\hline PCR grade water & To make up total volume up to $50 \mu \mathrm{l}$ \\
\hline
\end{tabular}

\section{Effect of Primer concentration}

Very low primer concentration does not succeed in producing enough amplicons to give a visible band. On the other hand too high primer concentration gives rise to non-specific bands

Table-3: Reaction mixture for optimising Primer concentration for PCR amplification of CTLA-4 gene

\begin{tabular}{|l|l|}
\hline Template DNA & $2 \mu \mathrm{l}$ \\
\hline $\begin{array}{l}\text { Primer mix (both forward and } \\
\text { reverse) }\end{array}$ & $\begin{array}{l}\text { Sufficiently diluted to make concentrations 0.125, 0.25, 0.5, } \\
1.5 \mu \mathrm{M} \text { in 5 different tubes }\end{array}$ \\
\hline dNTPs & $2 \mu \mathrm{l}$ \\
\hline $\begin{array}{l}\text { Taq DNA polymerase assay buffer } \\
(10 X)\end{array}$ & $5 \mu \mathrm{l}$ \\
\hline Taq DNA polymerase & $1 \mu \mathrm{l}$ \\
\hline PCR grade water & To make up total volume up to $50 \mu \mathrm{l}$ \\
\hline
\end{tabular}

\section{Effect of Magnesium Ions}

Magnesium ion concentration is a crucial factor affecting the performance of Taq DNA polymerase. It exists as dNTP-Mg complexs that interact with the sugar-phosphate backbone of nucleic acids. So altering the concentration of magnesium ions can lead to one primer/template pair behaving significantly different from another under identical conditions. Therefore, optimizing the concentration of magnesium ions for PCR performance is important. To check the optimal concentration of magnesium ions to be used in the amplification reaction, different concentrations of $\mathrm{MgCl}_{2}$ were used. All other factors of PCR were kept unchanged.

Table-4: Reaction mixture for optimising $\mathrm{MgCl}_{2}$ concentration for PCR amplification of CTLA-4 gene

\begin{tabular}{|l|l|}
\hline Template DNA & $\mathbf{2} \boldsymbol{\mu l}$ \\
\hline Forward primer & $2 \mu \mathrm{l}$ \\
\hline Reverse primer & $2 \mu \mathrm{l}$ \\
\hline dNTPs & $2 \mu \mathrm{l}$ \\
\hline Taq DNA polymerase assay buffer without $\mathrm{MgCl}_{2}(10 \mathrm{X})$ & $5 \mu \mathrm{l}$ \\
\hline $\mathrm{MgCl}_{2}$ & Sufficiently diluted to produce concentrations from $0.5-3.0 \mathrm{mM}$ \\
\hline Taq DNA polymerase & $1 \mu \mathrm{l}$ \\
\hline PCR grade water & To make up total volume up to $50 \mu \mathrm{l}$ \\
\hline
\end{tabular}

\section{Effect of enhancing reagent}

A variety of PCR additives and enhancing agents can be used to increase the specificity and consistency of yield, in PCR reactions. There are number of additives that may have beneficial effects on some amplification so it is impossible to predict which agent will be used in a particular context and therefore they must be empirically tested for each combination of template and primers. Higher yields can be achieved by stabilizing or enhancing the polymerase activity with enzyme-stabilizing proteins such as bovine serum albumin (BSA or gelatin), enzyme-stabilizing solutes such as glycerol, solubility- enhancing solvents like dimethyl sulfoxide (DMSO) has been shown to improve reaction yield during PCR.

Triton X-100, Tween 20 may increase yield but may also increase non-specific amplification. Ammonium sulphate affects the denaturing and annealing temperature of the DNA, as well as the enzyme activity.

\section{RESULTS \& DISCUSSIONS \\ DNA Isolation}

Very good amount of genomic DNA was isolated from most of the blood samples. The same was evident on the agarose gel. 

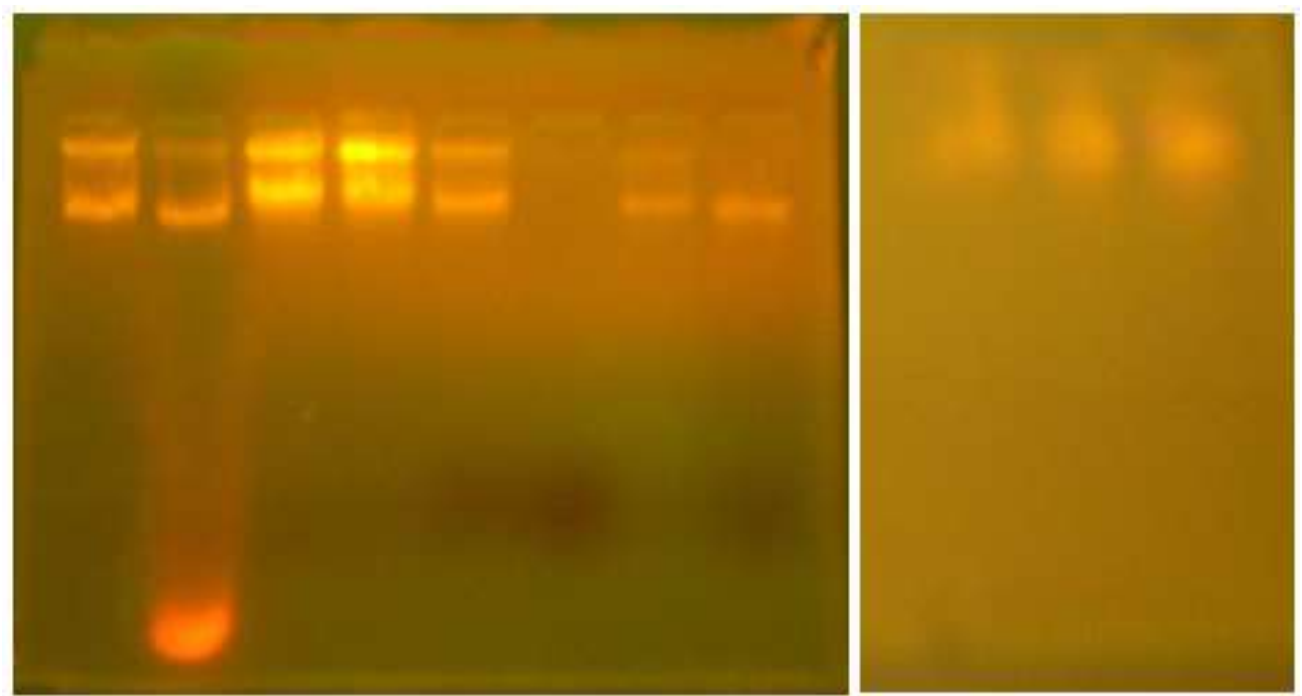

Fig-1: Genomic DNA isolated from blood samples

\section{Effect of Taq Polymerase}

Different concentrations of Taq polymerase were used for PCR reactions using same conditions. The $2 \%$ agarose gel electrophoresis revealed PCR products of acceptable intensity in reactions containing between $1.25-1.75 \mathrm{U}$ with maximum intensity in $1.75 \mathrm{U}$. When Taq polymerase was used in a concentration higher than $1.75 \mathrm{U}$, then non-specific bands with overall faint intensity were observed.

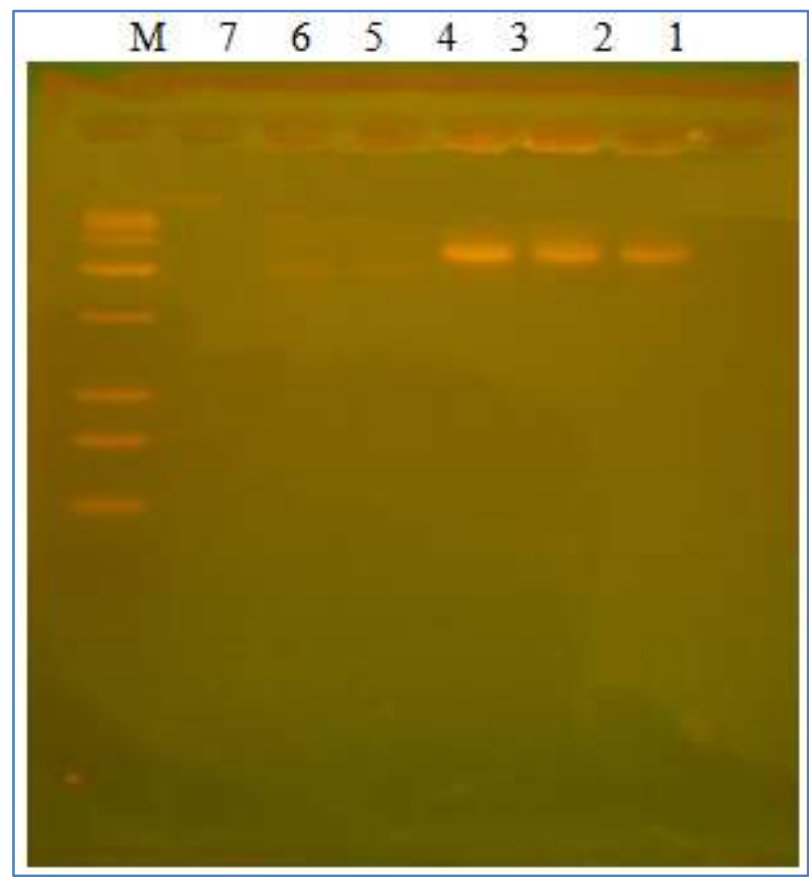

Fig-2: Effect of varying Taq polymerase concentrations on PCR amplification of CLTA4 gene (Lane M: 1Kb DNA ladder, Lane1: 1.0U, Lane2:1.25U, Lane3:1.5U, Lane4: 1.75U, Lane5: 2.0U \& Lane6: 2.5U)

\section{Effect of dNTPs}

Higher concentrations of dNTPs than $200 \mathrm{mM}$ had inhibitory effects on the PCR reaction. Higher dNTPs require higher concentrations of $\mathrm{MgCl}_{2}$.

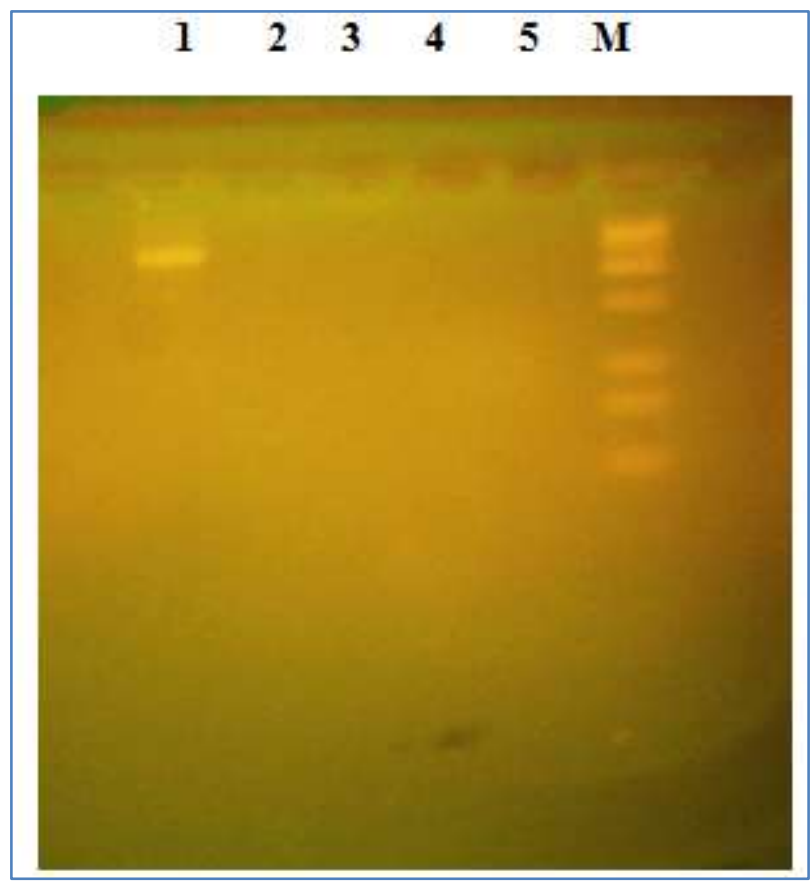

Fig-3: Effect of varying dNTPs concentrations on PCR amplification of CLTA4 gene (Lane M: 1Kb DNA ladder, Lane1: 200mM, Lane2:400mM, Lane3:600mM, Lane4: 800mM \& Lane5: $1000 \mathrm{mM})$

\section{Effect of primer concentration}

$0.125 \mu \mathrm{M}$ of primer concentration could not yield a visible band. Concentrations $0.25,0.5$ and $1.0 \mu \mathrm{M}$ resulted in adequate visible bands with maximum intensity in $1 \mu \mathrm{M}$ concentration. $1.5 \mu \mathrm{M}$ primer resulted in good amplification but secondary priming was observed and prominent non-specific bands were seen. 


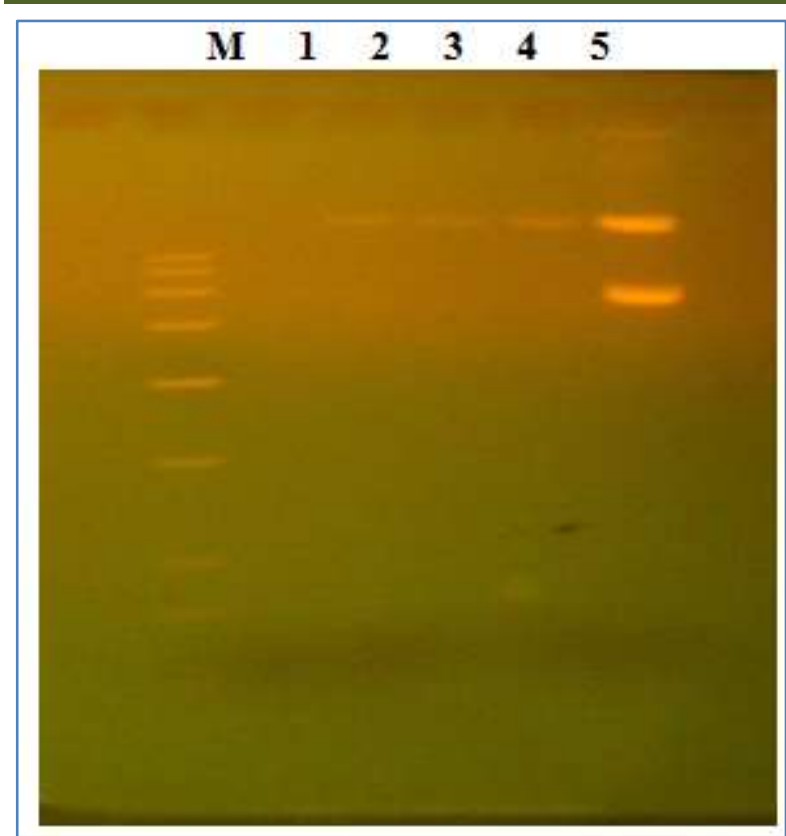

Fig-4: Effect of varying primer concentrations on PCR amplification of CLTA4 gene (Lane M: 100bp DNA ladder, Lane1: 0.125 $\mu$ M, Lane2:0.25 $\mu$ M, Lane3:0.5 $\mu$ M, Lane4: 1.0 $\mu \mathrm{M} \&$ Lane5: $1.5 \mu \mathrm{M})$

\section{Effect of $\mathrm{MgCl}_{2}$ concentration}

From the results it was very clear that the band intensity was maximum in lane 4. It means the optimal $\mathrm{MgCl}_{2}$ concentration for PCR of CTLA4 gene was $2.0 \mathrm{mM}$. Also lower concentration $(0.5 \mathrm{mM})$ failed to yield visible bands and higher concentrations (2.5-3.0mM) yielded result but somewhat less amplification product. Bands were also present on 1.0 and $1.5 \mathrm{mM}$ but results were not adequate.

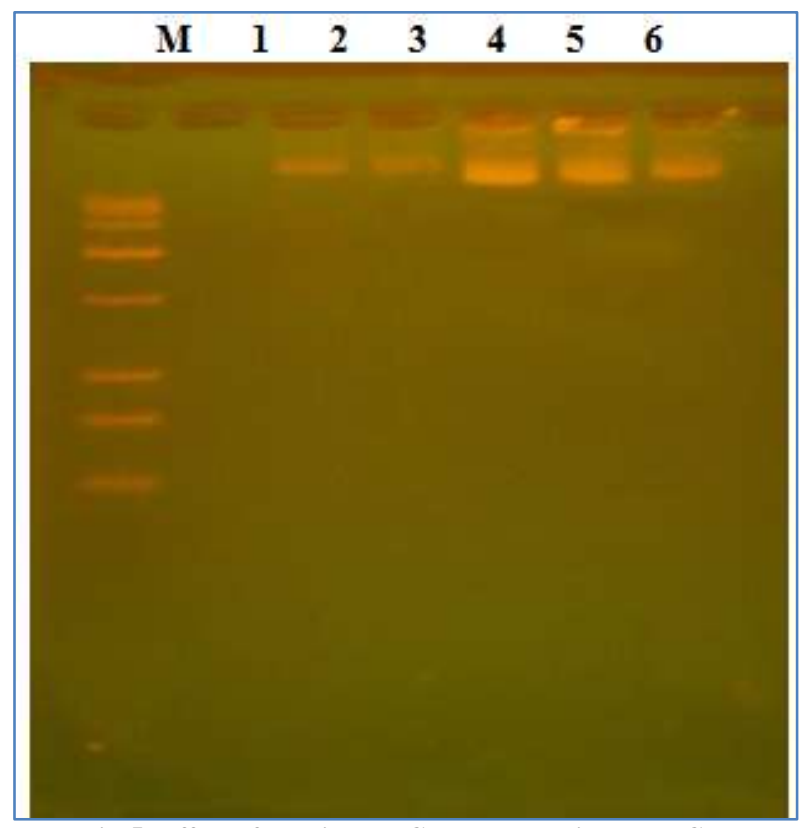

Fig-5: Effect of varying $\mathrm{MgCl}_{2}$ concentrations on PCR amplification of CLTA4 gene (Lane M: 100bp DNA ladder, Lane1: 0.5mM, Lane2:1.0mM, Lane3:1.5mM, Lane4: 2.0mM, Lane5: 2.5mM \& Lane6: 3.0mM)

\section{Effect of enhancing reagent}

Except gelatin and BSA, none of the enhancing agents have any effect on amplification of CTLA4. Maximum effect was by addition of gelatin.

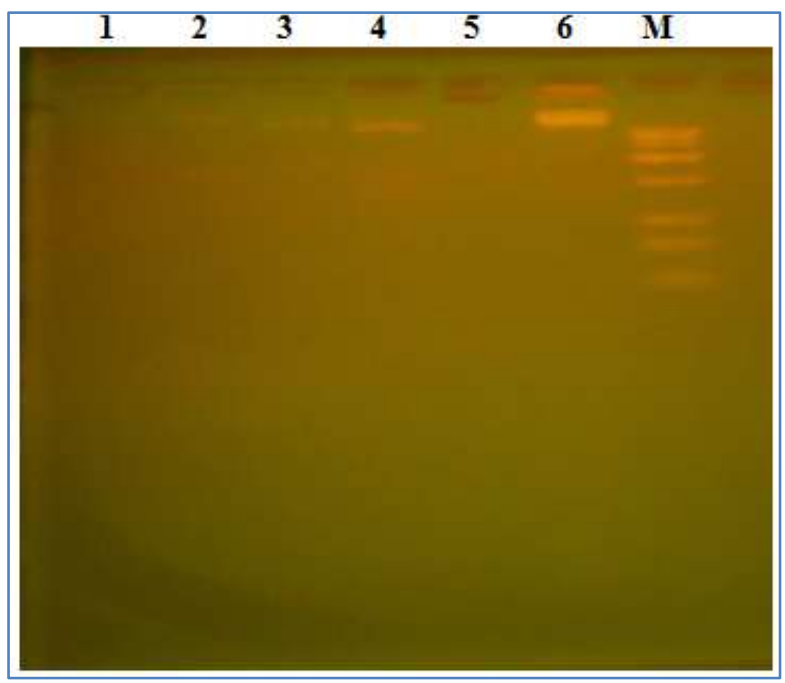

Fig-6: Effect of varying Taq polymerase concentrations on PCR amplification of CLTA4 gene (Lane M: 100bp DNA ladder,

Lane1: tween20, Lane2:TritonX100, Lane3: DMSO, Lane4: BSA, Lane5: Glycerol \& Lane6: Gelatin)

\section{CONCLUSION}

Since its existence, polymerase chain reaction has always served as one of the most used techniques to draw important conclusion in genetic and other relation researches involving genomic sciences. In genetics in particular, PCR has been exploited as a tool to study genetic mutations, roles of genes in important genetic diseases, genetic polymorphisms, and detection of diseases related ancestral risk factors. Moreover a successful PCR reaction always needs a specifically optimized reaction mixture. Once optimized for a given set of primers in any laboratory, the conclusions can be used to establish a result producing protocol for repeated PCR reaction without any confusion.

The cytotoxic T-lymphocyte-associated protein 4, CTLA-4, gene is located on chromosome 2q. Under normal circumstances, the CTLA-4 protein acts to suppress $\mathrm{T}$-cell activation during normal immune response in order to prevent $\mathrm{T}$-cell over activity. Decreased or absent CTLA-4 activity permits uninhibited T-cell activity and a prolonged, unregulated immune response, making CTLA-4 an attractive candidate gene for autoimmunity. Indeed, the CTLA-4 gene has been found to be associated with many autoimmune diseases including rheumatoid arthritis. Rheumatoid arthritis (RA) is a chronic, systemic inflammatory disorder that may affect many tissues and organs, but principally attacks flexible (synovial) joints. It can be a disabling and painful condition, which can lead to substantial loss of functioning and mobility if not adequately treated. It is an autoimmune disease in which the body's immune system attacks itself. 
The present study concentrated on optimization of amplification of CTLA4 gene from genomic DNA isolated from rheumatoid arthritis patients. The conditions were optimized for different parameters such as Taq DNA polymerase concentration, dNTPs concentrations, Primer concentrations, $\mathrm{MgCl}_{2}$ concentration and different enhancing agents. The results obtained were used to develop the protocol for amplification reaction. We hope these results will help others researchers to quickly amplify CLTA4 genes without going through the hectic procedures of optimizations in future.

\section{REFERENCES}

1. Lei C, Dongqing Z, Yeqing S, Oaks MK, Lishan C, Jianzhong J, Jie Q, Fang D, Ningli L, Xinghai H, DaMing R. Association of the CTLA-4 gene with rheumatoid arthritis in Chinese Han population. European journal of human genetics. 2005 Jul;13(7):823-8.

2. Ahmed MB, Alim A, Kabir AH. Optimization of different parameters of polymerase chain reaction for Arabidopsis thaliana At4g20020 gene. Minerva Biotecnologica. 2012 Mar 1;24(1):23-6.

3. Lalam N. Estimation of the reaction efficiency in polymerase chain reaction. Journal of theoretical biology. 2006 Oct 21;242(4):947-53.

4. Cha RS, Thilly WG. Specificity, efficiency, and fidelity of PCR. PCR Methods Appl. 1993 Dec $1 ; 3(3): 18-29$.

5. Innis MA, Gelfand DH, Sninsky JJ, White TJ, editors. PCR protocols: a guide to methods and applications. Academic press; 2012 Dec 2.

6. Gibson UE, Heid CA, Williams PM. A novel method for real time quantitative RT-PCR. Genome research. 1996 Oct 1;6(10):995-1001.

7. Ernie-Muneerah MA, Ahmad N, Ang KC, Ampeng A. Polymerase chain reaction (PCR) optimization for COIIrRNA gene fragment of Malaysian Leaf Monkeys. J. Wildl. Parks. 2005;22:71-6.
8. Tabone T, Mather DE, Hayden MJ. Temperature switch PCR (TSP): Robust assay design for reliable amplification and genotyping of SNPs. BMC genomics. 2009 Dec;10(1):1-4.

9. Goronzy JJ, Weyand CM. T-cell regulation in rheumatoid arthritis. Current opinion in rheumatology. 2004 May 1;16(3):212-7.

10. Kremer JM, Westhovens R, Leon M, Di Giorgio E, Alten R, Steinfeld S, Russell A, Dougados M, Emery P, Nuamah IF, Williams GR. Treatment of rheumatoid arthritis by selective inhibition of T-cell activation with fusion protein CTLA4Ig. New England Journal of Medicine. 2003 Nov 13;349(20):1907-15.

11. Lee HJ, Li CW, Hammerstad SS, Stefan M, Tomer Y. Immunogenetics of autoimmune thyroid diseases: a comprehensive review. Journal of autoimmunity. 2015 Nov 1;64:82-90.

12. Kotsa K, Watson PF, Weetman AP. A CTLA- 4 gene polymorphism is associated with both Graves' disease and autoimmune hypothyroidism. Clinical endocrinology. 1997 May;46(5):551-4.

13. Donner H, Rau H, Walfish PG, Braun J, Siegmund T, Finke R, Herwig J, Usadel KH, Badenhoop K. CTLA4 alanine-17 confers genetic susceptibility to Graves' disease and to type 1 diabetes mellitus. The Journal of Clinical Endocrinology \& Metabolism. 1997 Jan 1;82(1):143-6.

14. Yanagawa T, Taniyama M, Enomoto S, Gomi K, Maruyama H, Ban Y, Saruta T. CTLA4 gene polymorphism confers susceptibility to Graves' disease in Japanese. Thyroid. 1997 Dec;7(6):843-6.

15. Villanueva R, Inzerillo AM, Tomer Y, Barbesino G, Meltzer M, Concepcion ES, Greenberg DA, MacLaren N, Sun ZS, Zhang DM, Tucci S. Limited genetic susceptibility to severe Graves' ophthalmopathy: no role for CTLA-4 but evidence for an environmental etiology. Thyroid. 2000 Sep;10(9):791-8. 